\title{
FACTORS AFFECTING STUDENT INTEREST TO CONTINUE STUDYING ABROAD
}

\author{
By: \\ Miftakhul Khoirun Niffa \\ Accounting Education Deaprtment Yogyakarta State University \\ Miftakhul.k.niffa@gmail.com \\ Sukirno \\ Lecturer of Accounting Education Deaprtment Yogyakarta State University
}

\begin{abstract}
This study aimed to know the influence of (1) English Ability (2) Education Cost (3) Perception about Abroad Education Quality, and (4) English Ability, Education Cost, and Perception about the Quality of Education Abroad simultanously toward Interest to Continue Studying Abroad of Excellent Class Students of Economic Faculty Yogyakarta State University 2014. Data Collection Technique used in this research were documentation and questionnaire. Population of this research was the excellent class students of Economic Faculty YSU 2014. The research showed that there is a (1) positive and significant influence of English Ability toward Interest to Continue Studying Abroad 2) negative and significant influence of Education Cost toward Interest to Continue Studying Abroad, (3) positive and significant influence of Perception about Abroad Education Quality toward Interest to Continue Studying Abroad (4) influence of English Ability, Education Cost, and Perception about Abroad Education Quality simultanously toward Interest to Continue Studying Abroad.
\end{abstract}

Keywords: Interest to Continue Studying Abroad, Education Cost, English Ability, Perception

\section{INTRODUCTION}

People's interest is strongly influenced by several factors as proposed by Djaali (2013: 121), "Interest is essentially the acceptance of a relationship between oneself with something outside of self, the closer the relationship is, the greater the interest." Factors that encourage a person to continue study abroad derived from within a person, such as the ability of the individual English language. Usually someone who has English language skills above the average will choose to continue study abroad and develop the skills that have been owned. Good English skills will help them complete their studies and be more confident to continue their studies abroad.

Deviney and his colleagues (2014) conducted a study entitled "Why some students study abroad and others stay". The study investigated factors affecting student interest from two higher education institutions in the United States in choosing to continue studies abroad. Factors that influence in the study varied from the education cost, support from family, difficulty in credit transfers due to differences in curriculum, and personal relationships. Stroud (2015) proves empirically in a dissertation entitled "Should I Stay or Should I Go?: Factors Impacting the Decision to Study Abroad Among Students Who Have Expressed Intent", that decision-making studies abroad in case studies of students who have stated their interest are influenced by factors Grade Passing Average (GPA), foreign language proficiency factor, education cost factor, and inaccurate 
graduation factor. Loberg (2012) conducted a study of US students at the University of California entitled "Exploring Factors that Lead to Participation in Study Abroad". The results revealed that support from origin university and curriculum / academic integration is a key factor affecting students to study abroad.

Internationalization programs of the campus aim to support students to have the readiness to continue study abroad for the creation of output and outcome which is qualified and has a global competitiveness. However, the interest to continue study abroad that happened so far in YSU is quite low, especially in the students of excellent class who are students who are equipped with more international skills and insights than regular class students. Whereas, study abroad is an important tool in education along with further study is a major component of the internationalization effort of the campus (Loberg, 2012). From these explanations can be concluded if further studies abroad support the occurrence of campus internationalization.

People's interest is strongly influenced by several factors as proposed by Djaali (2013: 121), "Interest is essentially the acceptance of a relationship between oneself with something outside of self, the closer the relationship is, the greater the interest." Factors that encourage a person to continue study abroad derived from within a person, such as the ability of the individual English language. Usually someone who has English language skills above the average will choose to continue study abroad and develop the skills that have been owned. Good English skills will help them complete their studies and be more confident to continue their studies abroad.

Deviney and his colleagues (2014) conducted a study entitled "Why some students study abroad and others stay". The study investigated factors affecting student interest from two higher education institutions in the United States in choosing to continue studies abroad. Factors that influence in the study varied from the education cost, support from family, difficulty in credit transfers due to differences in curriculum, and personal relationships. Stroud (2015) proves empirically in a dissertation entitled "Should I Stay or Should I Go?: Factors Impacting the Decision to Study Abroad Among Students Who Have Expressed Intent", that decision-making studies abroad in case studies of students who have stated their interest are influenced by factors Grade Passing Average (GPA), foreign language proficiency factor, education cost factor, and inaccurate graduation factor. Loberg (2012) conducted a study of US students at the University of California entitled "Exploring Factors that Lead to Participation in Study Abroad". The results revealed that support from origin university and curriculum / academic integration is a key factor affecting students to study abroad.

Based on the preliminary observation of pre-research questionnaire on March 10, 2017 in the excellent class students of Accounting Education, Economic Education, Accounting and Management study program 2014, produced data from 26 students who completed the questionnaire. From the 26 students who completed the questionnaires, 19 students stated that they had an interest in continuing their studies, with only 8 students 
interested in further study abroad, two students were not interested in studying abroad, and the remaining nine were hesitant. While 5 students stated that they were still hesitant about whether they want to continue their studies or not, and 2 students expressed no interest to continue their studies. In the results of the pre-research survey, it is also known that the average student who are not interested in studying abroad is motivated by the English skills expressed by 6 students, the educational cost factors proposed by 5 students, and the socioeconomic status of the parents proposed by 2 students. While 5 students put forward the other factors such as ideas, academic ability, peer environment, and health conditions.

These earlier studies and the preliminary observations of the research indicate that most prove that decision-making for study abroad is influenced by education cost factor, family support and faculty, foreign language proficiency, curriculum and GPA. Based on the factors that influence the interest of study abroad in previous research, the researcher is interested to do research on the factors that influence the interest of continuing study abroad on the excellent class students of Economic Faculty YSU with the main focus on the factor of English ability, the education cost, and perceptions about abroad education quality with the title "The Influence of English Ability, Education Cost, and Perception about Abroad Education Quality toward Interest to Continue Studying Abroad of the Excellent Class Students of Economic Faculty Yogyakarta State University".

\section{RESEARCH METHODS}

This research is an ex post facto research that belongs to correlation study or causal research. Ex post facto research is a study in which the independent variables that influence the dependent variable have occurred when the research is done, so that the researcher can not manipulate and control the independent variable (Arikunto, 2013). This research is included in correlation research because this study involves data collection actions to determine whether there is a relationship and the level of relationship between two or more variables. In its implementation, this study aims to find the influence of independent variables, namely English Ability (X1), Education Cost (X2), and Perception about Abroad Education Quality (X3) on dependent variable that is Interests to Continue Studying Abroad (Y). While the approach used is a quantitative approach because the data obtained will be realized in the form of numbers and analyzed by using SPSS program.

The population in this study are the excellent class students of Accounting Education, Economics, Accounting, and Management study program of FE YSU 2014 with the total of 84 students.

Consideration in choosing the excellent class students as a research subject is because they are a student who is expected to have advantages and superiority such as having a good English ability and more international insight compared to regular class students. Researchers want to know whether with the advantages possessed, the excellent class students also have an interest to continue study abroad.

The technique used to determine the sample is a simple random sampling technique that is taking samples from all members of the population conducted randomly without regard to the strata in the 
population members (Sugiyono, 2015). Sampling is done by lottery method.

The determination of the number of samples can be calculated using the Slovin formula, as mentioned by Rahayu Setyaningsih (2016: 64) as follows:

$$
\mathrm{n}=\frac{\mathrm{N}}{1+\mathrm{Ne}^{2}}
$$

Keterangan:

$\mathrm{n}$ = Sample Quantity

$\mathrm{N}=$ Population Size

$\mathrm{E}=$ Critical value (limit of accuracy) desired (Percentage of inaccuracy due to sampling error / $5 \%$ )

Based on the formula then it can be seen that the number of samples taken in this study are:

$$
\mathrm{n}=\frac{84}{1+84 \times(0,05)^{2}}=69,42
$$

Then it is known that the sample quantity that will be used is at least 69.42 rounded to 70 students. Because the population in this study consists of 4 classes, then the calculation is proportionaly done.

The procedure in this research is to create a set of research instruments which then be tested in advance with the research trial test amounted to 30 people. After that, the data of the test instrument is analyzed by validity and reliability test. When the research instrument is feasible, the next step is to take research data on the subject of research.

This research used Documentation and Quastionnaire as the data collection method. In carrying out the method of documentation, researchers can investigate books, magazines, documents, regulations, meeting minutes, diaries, and so on. This documentation method is used to obtain data on the number of students and English proficiency score data (ProTEFL).

Questionnaire method is used to obtain data on Education Cost, Perception about Abroad Education Quality, and Interest to Continue Studying Abroad from the excellent class students of Economic Faculty YSU 2014.

Data analysis technique used in this research were descriptive analysis, prerequisite analysis test, hypotheses test, and calculate effective contribution and relative contribution.

Descriptive analysis in this research is used to analyze the data obtained from the respondents through questionnaires that have been filled by them during the study which then presented in the form of data description of each variable (independent variable and dependent variable). Description of data used include description of the data, description of respondent characteristic, and description of research variable.

Prerequisite analysis test include the Linearity Test, Multicollinearity Test, and Heteroscedasticity Test. Hypotheses test used in ths research was Multiple Linear Regression.

\section{RESULT OF RESEARCH AND DISCUSSION}

Table 1. Research Data Description

\begin{tabular}{|l|r|r|r|r|r|}
\hline & N & Min. & Max. & Mean & $\begin{array}{l}\text { Std. } \\
\text { Dev. }\end{array}$ \\
\hline $\begin{array}{l}\text { English } \\
\text { Ability }\end{array}$ & 70 & 325 & 570 & 452,27 & 31,16 \\
$\begin{array}{l}\text { Education } \\
\text { Cost }\end{array}$ & 70 & 32 & 52 & 42,17 & 4,05 \\
\hline
\end{tabular}




\begin{tabular}{|l|r|r|r|r|r|}
\hline & N & Min. & Max. & Mean & $\begin{array}{r}\text { Std. } \\
\text { Dev. }\end{array}$ \\
\hline $\begin{array}{l}\text { Perception } \\
\text { about } \\
\text { Abroad } \\
\text { Education } \\
\text { Quality }\end{array}$ & 70 & 25 & 38 & 30,74 & 2,80 \\
$\begin{array}{l}\text { Interest to } \\
\text { Continue } \\
\text { Study } \\
\text { Abroad } \\
\text { Valid N } \\
\text { (listwise) }\end{array}$ & 70 & 25 & 48 & 32,84 & 3,69 \\
\hline
\end{tabular}

Source: Primary Data Processed

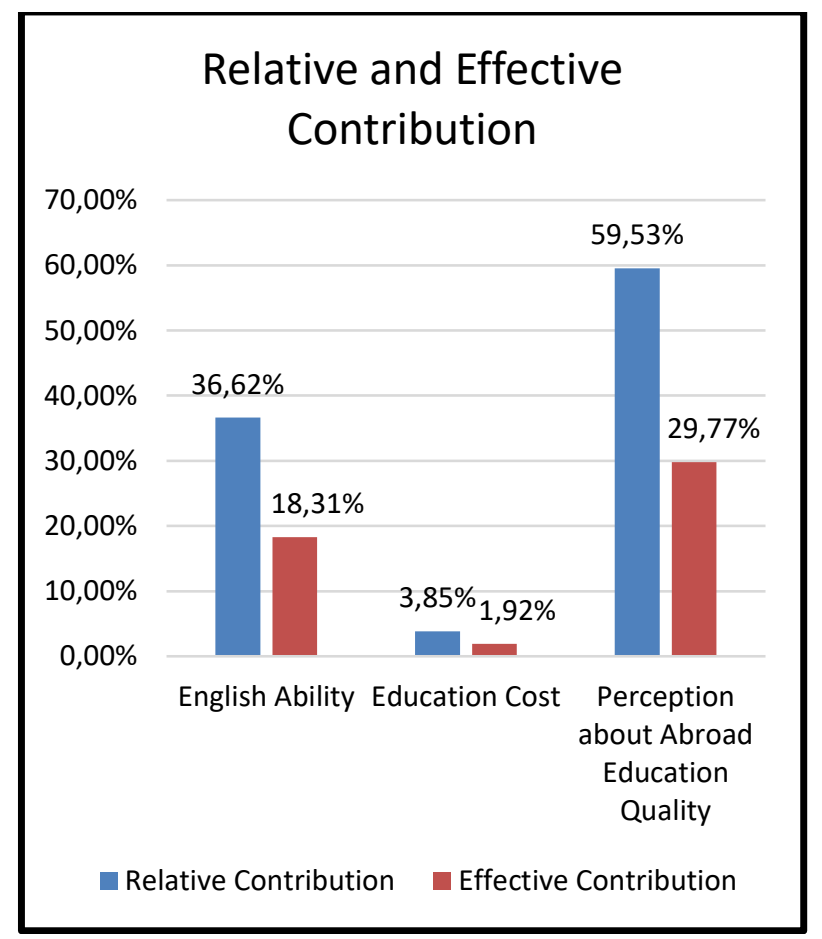

Figure 1. Summary of Relative and Effective Contribution

Indicators included in the English Ability variable are measured through ProTEFL test scores of students issued by P2LB LPPMP YSU. Based on the description of research data it can be seen that the English Ability the Excellent Class Students of Economic Faculty YSU 2014 is on the trend of medium category with the frequency of 62 students $(88,57 \%)$. So, it can be said that most of the excellent class students of Economic Faculty YSU 2014 have medium English ability.

The result of the research supports the first hypothesis that the English Ability (X1) variable has a significant positive influence toward the Interest to Continue Studying Abroad of the excellent class students of Economic Faculty YSU 2014 (Y). This is indicated by the value of regression coefficient X1 of 0.331 which states that each increase in English ability of 1 unit will increase the Interest to Continue Studying Abroad the excellent class students of Economic Faculty YSU 2014 amounted to 0.331 units. This means the direction of the model is positive. Based on the data analysis results obtained $t_{\text {count }}$ value of 5.010 whose value is above $t_{\text {table }}$ of 1.9976 . This result indicates that $t_{\text {count }}$ is greater than $t_{\text {table }}$, it means there is a positive influence of English Ability toward Interest to Continue Studying Abroad the excellent class students of Economic Faculty YSU 2014. Besides, value probability significance of English Ability equal to 0,002 which is less than 0,05 it can be stated that the English Ability has a significant influence toward the Interest to Continue Studying Abroad the excellent class students of Economic Faculty YSU 2014 so that hypothesis 1 is supported with a trust level of $95 \%$. These results indicate that the higher the English Ability then the higher the Interest to Continue Studying Abroad the excellent class students of Economic Faculty YSU 2014, otherwise if the lower the English Ability, the lower the Interest to Continue 
Studying Abroad the excellent class students of Economic Faculty YSU 2014.

These results reinforce previous research conducted by Jasmine R. Philips, Doctor of Physiology, University of Miami entitled Examining Predictors of U.S. Student Intent to Study Abroad from a Communication Perspective. The results showed that students' interest in studying abroad was influenced by online communication with peers and faceto-face communication with people important to them such as faculty, mentors, parents, and friends who needed English language skills which is quite adequate.

This result has the same finding with the previous research stated above is predicted because the same purpose of English which described by the researcher. This research describes the purpose of English Ability based on Kemendikbud that is English Ability has the purpose namely as a communication in English, understanding of English as a system, cultural undersstanding, and general knowledge. English Ability as a communication has a purpose to extend students interpersonal relations to the international level and to gain access to world of knowledge, ideas, and values in English. This means that the students has to access it from their abroad faculty member, mentors, parents, and friends.

Indicators included in the Education Cost variable are the costs for the improvement of teaching and learning activities, the maintenance and replacement of educational facilities and infrastructure, the improvement of student activities, the welfare costs, the university's households, and the cost of guidance, monitoring and reporting. Based on the description of research data can be seen that the Education Cost variable is on the trend of high category with the frequency of 30 students $(42.86 \%)$. So, it can be said that most of the excellent class students of Economic Faculty YSU 2014 think that the Education Cost abroad is high.

The result of the research supports the second hypothesis that the Education Cost (X2) has a significant negative influence toward the Interest to Continue Studying Abroad of the excellent class students of Economic Faculty YSU 2014 (Y). This is indicated by the value of $\mathrm{X} 1$ regression coefficient of -0.072 which stated that any increase of Education Cost of 1 unit will decrease Interest to Continue Studying Abroad of the excellent class students of Economic Faculty YSU 2014 by 0.072 units. This means the direction of the model is negative. Based on the data analysis results obtained $t_{\text {count }}$ value of 3,566 whose value above $t_{\text {table }}$ of 1.9976. These results indicate that $t_{\text {count }}$ is greater than $t_{\text {table }}$, this means there is a significant negative influence of the Education Cost toward Interest to Continue Studying Abroad of the excellent class students of Economic Faculty YSU 2014. In addition, the value of probability significance of Education Cost of 0.032 is smaller than 0.05, it can be stated that the Education Cost has a significant negative influence toward the Interest to Continue Studying Abroad of the excellent class students of Economic Faculty YSU 2014 so that hypothesis 2 is supported with a trust level of $95 \%$. These results indicate that the higher the education cost, the lower the Interest to Continue Studying Abroad the excellent class students of Economic Faculty YSU 2014, otherwise the lower the Education Cost the higher the Interest to Continue Studying Abroad the 
excellent class students of Economic Faculty YSU 2014.

These results reinforce the theoretical description of the Journal by David Deviney, et al (2014) entitled Why some students study abroad and others stay conducted at several universities in the United States. The results of his research indicate that continuing studies abroad can provide students with a good intellectual development, such as a good open mind and have a higher tolerance attitude. However, there are several factors that influence students in making decisions to continue study abroad, namely the education cost, lack of support from the family, difficulties in the process of credit transfer, and personal relationships of students.

This result has the same finding with the previous research stated above is predicted because the education cost is the classic and basic problems of the students who want to continue study abroad. Like the statements of Riani Nurainah Lisnasari and Fitriany (2008) that the expensive education cost has become a classic problem for almost all Indonesians who are studying and has become a barrier to entry for low income people. The cost of further study abroad is much greater than that of in-country study.

Indicators included in the Perception about Abroad Education Quality are perceptions of resources, responsibilities, curriculum, and personnel of educational institutions. Based on the description of research data can be seen that the Perception about Abroad Education Quality is in the low category tendency with the frequency of 30 students $(42.86 \%)$. So, it can be said that most of the excellent class students of Economic Faculty YSU 2014 believe that the quality of education abroad is low.
The results support the third hypothesis that the Perception about Abroad Education Quality (X3) have a significant positive influence toward the Interest to Continue Studying Abroad of the excellent class students of Economic Faculty YSU 2014 (Y). This is indicated by the value of regression coefficient X3 of 1.374 which states that any increase in Perception about Abroad Education Quality by 1 unit will increase the Interest to Continue Studying Abroad the excellent class students of Economic Faculty YSU 2014 of 1.374 units. This means the direction of the model is positive. Based on the results of data analysis obtained $t_{\text {count }}$ value of 9,822 whose value above $t_{\text {table }}$ of 1.9976. These results indicate that $t_{\text {count }}$ is greater than $t_{\text {table }}$, this means there is a significant positive influence Perception about Abroad Education Quality toward Interest to Continue Studying Abroad of the excellent class students of Economic Faculty YSU 2014. In addition, the probability value of the significance of the Perception about Abroad Education Quality is 0,000 less than 0.05 , it can be stated that the Perception about Abroad Education Quality has a significant positive influence toward the Interest to Continue Studying Abroad of the excellent class students of Economic Faculty YSU 2014 so that hypothesis 3 is supported with a trust level of $95 \%$. These results indicate that the higher the Perception value about Abroad Education Quality the higher the interest to continue studying abroad the excellent class students of Economic Faculty YSU 2014, otherwise if the lower the value of the Perception about Abroad Education Quality thelower the interest to continue studying abroad of the excellent class students of Economic Faculty YSU. 
The results of this study also strengthen the results of previous research in the form of a dissertation conducted by Lisa Loberg (2012), Doctor of Education, University of California, Los Angeles entitled Exploring Factors that Lead to Participation in Study Abroad. The results of the study indicate that the factors that influence the student's decision to continue study abroad are the institutional culture abroad, faculty support for credit transfer, career network after continuing study, program development, and some barriers to continue study abroad such as the growing myths abroad, perceptions, and cost / financial factors.

This result has the same finding with the previous research stated above is predicted because the perception about abroad education quality in this research and the previous research has the same characteristic of the way interpret something on its respondent. Jalaluddin Rahmat (2007) states that perception is the observation of objects, events or relationships obtained by concluding information and interpreting messages. Even tough every people has their own tendency to interpret something depend on their own factor like experiences owned by individuals, but the nature of human is always feel safe and comfort if they are on their comfort zone, in this case is in their own country living

The results showed that there is a significant influence of English Ability, Education Cost, and Perception about Abroad Education Quality simultaneously toward the Interest to Continue Studying Abroad. This is indicated by the test results with the $F$ test obtained $F_{\text {count }}$ value of 57.564 with a significance value of $\mathrm{F}$ of 0.000 or $\mathrm{F}<0.05$. The result of multiple regression test shows that the coefficient of determination $\left(R^{2}\right)$ is 0,50 or $50 \%$. The value of the coefficient of determination shows the effective contribution of the three independent variables to the dependent variable. This effective contribution means that English Ability, Education Cost, and Perception about Abroad Education Quality influence $50 \%$ Interest to Continue Study Abroad while the remaining $50 \%$ is influenced by other variables not examined in this study.

This study supports the results of research conducted by April H. Stroud, Doctor of Education, University of Massachusetts entitled Should I Stay or Should I Go?: Factors Impacting the Decision to Study Abroad Among Students Who Have Expressed Intent. The results show that studies abroad have excellent benefits, including open-mindedness and adaptation to foreign environments, new relationships, high tolerance, and so on. However, there are several factors that encourage someone to have a decision to study abroad. Among the several internal and external factors that have been there, the financial factor is the most prominent in this study.

This result has not the same finding with the previous research stated above. In previous research, the most prominent factor is about the financial factor, but in this research the most prominent factor is in perception about abroad education quality variable with the result of relative contribution value of $59,53 \%$ and effective contribution value of $29,77 \%$, while education cost variable has the lowest value of relative contribution that is $3,85 \%$ and the effective contribution value of $1,92 \%$.

It is predicted because of some reason. First, most of the Indonesians (Subject of this 
research) rely their abroad education cost on scholarship. This can be seen on the result of questionnaire that showed the increasing of interest to continue studying abroad after they were given the choice of scholarchip in education cost variable. So, it can be predicted that Indonesians thought if the ducation is not too prominent as the factor affecting the interest to continue studying because they rely their education cost on scholarship they plan to get. Second, it can be predicted that the Indonesian has more negative perception about abroad education quality than people of other country. It makes them thought that Indonesia's education quality is better than abroad education quality, so they choose to continue studying in Indonesia rather than continue studying abroad.

\section{CONCLUSION AND SUGGESTION}

There is a positive and significant influence of English Ability toward Interest to Continue Studying Abroad of the Excellent Class Students of Economic Faculty YSU 2014. It can be shown with regression coefficient value of 0.331 . At the level of significance of $5 \%$, can be known $t_{\text {count }}$ amounting to 5.010 with a significance value of 0.002 because the regression coefficient has a positive value and significance value (p) $<0.05$ then it can be concluded there is a positive and significant influence English Ability toward Interest to Continue Studying Abroad of the Excellent Class Students of Economic Faculty YSU 2014.

There is a negative and significant influence of the Education Cost toward Interest to Continue Studying Abroad of the Excellent Class Students of Economic Faculty YSU 2014. It can be shown by the value of regression coefficient of -0.072 . At the significance level of 5\%, can be known $t_{\text {count }}$ amounting to 3.566 with a significance value of 0.032 because the regression coefficient has a negative value and significance value $(p)<0.05$ then it can be concluded there is a negative and significant influence of Education Cost toward Interest to Continue Studying Abroad of the Excellent Class Students of Economic Faculty YSU 2014.

There is a positive and significant influence of Perception about Abroad Education Quality toward Interest to Continue Studying Abroad at the Excellent Class Students of Economic Faculty YSU 2014. It can be shown by the value of regression coefficient of 1.374. At significance level of 5\%, can be known $t_{\text {count }}$ is amounting to 9,822 with significance value equal to 0,000 because regression coefficient has positive value and significance value (p) $<0,05$ it can be concluded there is positive influence and significant Perception about Abroad Education Quality toward Interest to Continue Studying Abroad at the Excellent Class Students of Economic Faculty YSU 2014.

There is influence of English Ability, Education Cost, and Perception about Abroad Education Quality toward Interest to Continue Studying Abroad of the Excellent Class Students of Economic Faculty YSU 2014. It is shown with $F_{\text {count }}$ value of 57,564 with $F$ significance value of 0,00 . Because of the significance value of $F<0.05$, it can be concluded that there is influence of English Ability, Education Cost, and Perception about Abroad Education Quality simultaneously toward Interest to Continue Studying Abroad of the Excellent Class 
Students of Economic Faculty YSU 2014. Coefficient of determination $\left(R^{2}\right)$ of 0.50 or $50 \%$. The value of the coefficient of determination shows $50 \%$ academic procrastination can be explained by the variable of English Ability, Education Cost, and Perception about Abroad Education Quality while the rest of $50 \%$ is explained by other variable which is not examined in this research. Effective contribution of each variable is $18,31 \%$ for English Ability variable, $1,925 \%$ for Education Cost variable and 29,765\% for Perception about Abroad Education Quality

Based on the results of research and conclusion above it can be given suggestions as follows:

Respondent argues that aboard universities do not charge students to create a system for reporting teaching and learning activities. This means that respondents think that the cost of reporting teaching and learning activities is not too costly. We recommend that respondents seek more detailed information related to the cost component of education at foreign universities in order to be a further consideration.

Respondents argue that abroad universities have better employee and employee recruitment systems than in Indonesia. This can lead to the perception that the quality of education abroad is still not good enough. For those interested in studying abroad should be able to find many references and information about overseas universities that want to be addressed so that information about the quality of education abroad obtained really accurate.

The study found that many community members around the respondents did not advise to continue their studies abroad. This suggests that external factors (the community environment) may affect the interest of continuing studies abroad. For respondents who are interested to continue their studying abroad should strengthen internal factors (internal interest) in order to improve and keep the interest to continue study abroad.

For further researchers who want to research and develop similar research, the authors suggest to do research not only within the scope of one-year generation students only, but can be in some generation or even within the university. In addition, it can also use more accurate data collection techniques rather than to a questionnaire such as by using in-depth interview techniques so that data obtained more accurate and not subjective.

\section{REFERENCES}

Arikunto, S. (2009). Dasar-dasar Evaluasi Pendidikan. Jakarta: PT Bumi Aksara.

Arikunto, S. (2013). Manajemen Penelitian. Jakarta: PT. Rineka Cipta.

Deviney, D., Vrba, T., Mills, L., \& Ball, E. (2014). Why Some Students Study Abroad and Others Stay. Research in Higher Education Journal Volume 25,8 .

Loberg, L. (2012). Explorig Factors that Lead to Participation in Study Abroad. Electronic Thesis and Dissertations UCLA.

Rahayu, S. dan R. Wedi Rusmawan. (2010). "Analisis Faktor-Faktor yang Mempengaruhi Minat untuk Mengikuti Program Pendidikan Profesi Akuntansi (PPAk)". Simposium Nasional Akuntansi XIII: Purwokerto. 
Jurnal Pendidikan Akuntansi Indonesia, Vol. XVI, No. 1, Tahun 2018

Miftakhul Khoirun Niffa \& Sukirno

$12-22$

Stroud, A. (2015). Should I Stay or Should I go?: Facctors Impacting the Decision to Study Abroad Among Students Who Have Expressed Intent. Dissertation.

Sugiyono. (2010). Statistika Untuk Penelitian. Bandung: Alfabeta. 